\title{
The endemic Mediterranean yelkouan shearwater Puffinus yelkouan: distribution, threats and a plea for more data
}

\author{
Karen Bourgeois and Eric Vidal
}

\begin{abstract}
The endemic Mediterranean yelkouan shearwater Puffinus yelkouan, elevated to the rank of species in 2002, is poorly monitored and studied. Despite this lack of data and the susceptibility of closely related species to threats at breeding sites and foraging areas, the yelkouan shearwater is currently considered to be at low risk of extinction. This review, based on published documents, personal communications with scientists and our own observations, summarizes available data on range, population size and trends, and on threats to the species' existence. Breeding sites range from the Marseille islands (France) to Bulgarian islands in the Black Sea but many are not confirmed. The estimated global population is $11,355-54,524$ pairs but most censuses are probably overestimates and the global population could be only a few thousand breeding pairs. There is evidence of a population decline and susceptibility to introduced mammals, particularly feral cats Felis catus and ship rats Rattus rattus, and to accidental bycatch in fishing gear. We highlight the lack of accurate and regular censuses of the species, and the alarming situation suggested by the little data available. We recommend that the yelkouan shearwater be categorized as Near Threatened on the IUCN Red List, encourage collaborative work to clarify its status, and make a plea for more data on the species' demography and ecology, and for the evaluation of terrestrial and marine threats.
\end{abstract}

Keywords Bycatch, introduced mammals, Mediterranean, Near Threatened, Puffinus yelkouan, status assessment, yelkouan shearwater.

This paper contains supplementary material that can be found online at http://journals.cambridge.org

\section{Introduction}

Ceabirds, particularly albatrosses and petrels, have expe$\checkmark$ rienced a dramatic deterioration of their conservation status (Butchart et al., 2004), and of the 328 seabird species currently recognized, $31.1 \%$ are considered globally threatened (IUCN, 2007). Reasons are the high sensitivity of

Karen Bourgeois (Corresponding author) and ERIC VIDAL Mediterranean Institute for Ecology and Palaeoecology (UMR CNRS 6116), Paul Cézanne University, Europôle Méditerranéen de l'Arbois, Avenue Philibert, BP 80, 13545 Aix-en-Provence cedex 04, France. E-mail karen.bourgeois@univ-cezanne.fr

Received 21 August 2006. Revision requested 6 November 2006. Accepted 22 January 2007. seabirds to the combination of both terrestrial and marine threats. Most seabirds that are threatened by invasive species on their breeding islands are also concurrently threatened by incidental mortality in commercial fisheries (Donlan \& Wilcox, 2008). Unfortunately, for many threatened seabirds demographic and ecological data are sparse, and it is thus difficult to make a reliable assessment of their conservation status (IUCN, 2007).

The yelkouan shearwater Puffinus yelkouan is a mediumsize procellarid strictly endemic to the Mediterranean Basin (including the Black Sea). It was previously considered to be a Mediterranean subspecies of the globally distributed Manx shearwater P. puffinus complex (Brooke, 1990; Warham, 1990) and later to be the oriental subspecies of the Mediterranean shearwater (Bourne et al., 1988; Heidrich et al., 1998). A taxonomic revision elevated the yelkouan shearwater to the rank of species, distinct from both the Manx shearwater and Balearic shearwater P. mauretanicus (Sangster et al., 2002). Whereas considerable attention has been given to the Balearic shearwater, leading to its categorization as Critically Endangered on the IUCN Red List (Arcos \& Oro, 2004; Oro et al., 2004; BirdLife International, 2006a; IUCN, 2007), few studies have dealt with the yelkouan shearwater. Consequently, this species remains the poorest known seabird in the Mediterranean, with little documentation of its distribution, population size and trends. Zotier et al. (1992) emphasized this lack of data and suggested that documented population sizes are overestimates.

Despite this paucity of data the yelkouan shearwater is considered to be at low risk of extinction (BirdLife International, 2006b; IUCN, 2007) and its European threat status is Secure (BirdLife International, 2004a), with population estimates of 14,750-52,300 pairs (IUCN, 2007) and 13,000-33,000 pairs (BirdLife International, 2004a). The yelkouan shearwater has only recently (2004) been added to Annex I of the European Union Wild Birds Directive. As a consequence, the attention of conservationists and scientists has not been drawn to this endemic species. Most of the endemic shearwater species formerly included in the Manx shearwater complex have, however, recently been categorized on the IUCN Red List (IUCN, 2007): Near Threatened (Puffinus opisthomelas), Endangered (P. huttoni, $P$. newelli) and Critically Endangered (P. auricularis, P. mauretanicus). 
Here we therefore provide for the yelkouan shearwater a comprehensive review of available data on range, population size and trends, and of threats to the species' existence. This review is based on an intensive literature survey, including grey and local literature (8o references, eight languages), and also includes 3 years of exchanges and personal communications with scientists, conservationists and NGOs from the 24 countries bordering the Mediterranean, Black and Azov Seas, and our own research data. Our aim is to provide an exhaustive compilation of available data concerning the yelkouan shearwater, identify the main gaps in this data, and to discuss the species' conservation status and priorities for its conservation. Finally, we make a plea for more data needed to fill the main gaps identified.

\section{Breeding locations, extent of occurrence and area of occupancy}

Seventy-five sites (i.e. islands) distributed among 10 countries were identified as certainly (40 sites) or possibly (35) harbouring yelkouan shearwater breeding colonies (Fig. 1, Appendix). The 40 breeding locations categorized as certain were those for which recent $(<70$ years old) evidence of breeding (i.e. eggs, chicks) were clearly stated and for which further information indicated clearly that breeding still occurs. The 35 possible breeding sites were considered as such from information linked to at-sea observations but actual breeding is unconfirmed.

Thus, if we consider only the 40 locations where breeding is certain, the area of occurrence of the yelkouan shearwater extends from the Marseille islands in the west (France; Zotier \& Vidal, 2004) to Bulgarian islands (Nankinov, 1993) in the Black Sea in the east, and from the Bulgarian islands in the north to Malta (Borg \& Sultana, 2002) in the south (Fig. 1, Appendix). This gives a yelkouan shearwater extent of occurrence (IUCN, 2001) of $c .1,117,100$ $\mathrm{km}^{2}$. With the 35 additional possible breeding locations this could extend to 1,322,100 $\mathrm{km}^{2}$. The area of occupancy (IUCN, 2001) is much smaller because of the patchy insular distribution of the species. Considering the entire surface area of the islands where the species breeds, the area of occupancy ranges from $1,209 \mathrm{~km}^{2}$ (for the 40 certain breeding sites) to $2,147 \mathrm{~km}^{2}$ (when the 35 possible breeding sites are included). However, yelkouan shearwater colonies are restricted to only a small part of the occupied islands $(<1 \%$; IMEP, unpubl. data), and based on this the area of occupancy is reduced to 12.1 and $21.5 \mathrm{~km}^{2}$, respectively.

\section{Breeding population estimate}

Only 17 of the 40 certain breeding locations have been surveyed (nest and calling bird counts at colonies), with an estimated on-land breeding population of 2,468-3,224 pairs. The other 23 certain breeding locations were only censused approximately by counting flocks at sea, and the authors estimated 3,431-6,185 additional pairs, giving a total of 5,8999,409 breeding pairs. For 31 of the 35 possible breeding locations, approximate counting at sea indicates a speculative additional breeding population of 5,456-45,115 pairs.

It is important to note that the estimation of shearwater breeding population by counting flocks at sea is questionable because of the risk of strong overestimation,

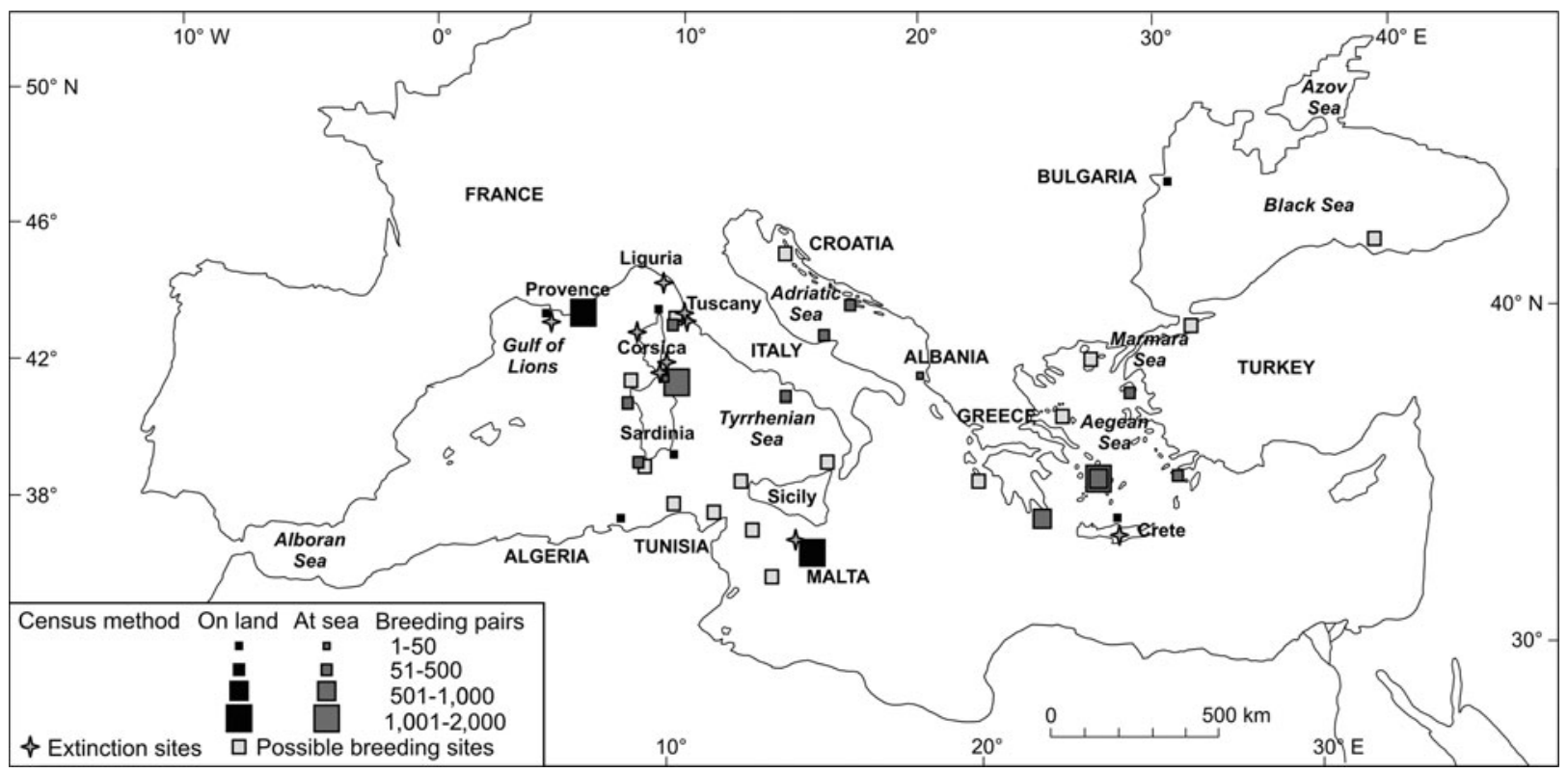

FIG. 1 Locations of breeding sites of the yelkouan shearwater in the Mediterranean Basin (including the Black Sea), with number of breeding pairs determined by censuses on land or at sea (including sites were breeding is both certain and possible, see text for details), and of the nine sites where the species appears to be extinct. 
imprecision and error (Bibby et al., 1992; Brichetti \& Fracasso, 2003). For example, flocks of up to 10,000 birds are regularly seen off some French Mediterranean islands but 4 years of intensive terrestrial survey gave a breeding population of $<1,600$ pairs (IMEP, unpubl. data). Moreover, the presence of shearwaters at sea (on feeding areas, for example) does not guarantee that the species breeds on nearby islands. Thus, the high breeding numbers given for some large populations (Italy, Greece and Turkey) are speculative and could be overestimates of 5-10 times the actual figure. For $77 \%$ of all the breeding sites (certain and possible) breeding population estimates are based on counts at sea. These numbers contribute to $78.3-94.1 \%$ of the overall population size estimates. Thus the lack of breeding confirmation for many of the possible breeding sites and the imprecision and probable overestimation for most given population sizes suggest that the yelkouan shearwater world population is likely to be at the low end of previous estimate ranges (i.e. $<15,000$ pairs). Until data is collected from data deficient areas (especially Turkey, Italy and Greece), we cannot exclude the possibility that the global yelkouan shearwater population may consist of only 5,899-9,409 pairs.

\section{Important marine areas}

Eight marine areas have been reported as important feeding, moulting or migration areas for yelkouan shearwaters, with regular observations of flocks of thousands of birds (Fig. 2). The first returns to breeding sites occur in late October or early November, egg-laying from mid March to early April, hatching in May and fledging in July to early August (Zotier 1997; K. Bourgeois \& E. Vidal, pers. obs.). The Aegean Sea and Marmara-Black-Azov Seas are two areas used throughout the year (Handrinos \& Akriotis, 1997; Nankinov, 2001). The Gulf of Lions-ProvenceLiguria-northern Tyrrhenian Sea, west of Sicily and the Algerian-Tunisian coast can be considered important feeding areas during the breeding season (Thibault \& Bonaccorsi, 1999; Conéjéro \& Beaubrun, 2000; Insenmann \& Moali, 2000; Brichetti \& Fracasso, 2003; Isenmann et al., 2005; IMEP, unpubl. data). The Alboran Sea, northern Adriatic Sea and the Israeli coast are important areas for moulting, feeding and passage during the interbreeding period (Markovec, 1995; Shirihai et al., 1996; Stipčević \& Lukač, 2001; Brichetti \& Fracasso, 2003; Thévenot et al., 2003).

\section{Population trends}

With the exception of Maltese and French colonies (Borg \& Sultana, 2002; Zotier \& Vidal, 2004; IMEP, unpubl. data), no yelkouan shearwater populations are monitored either at sea or on land. It is therefore difficult to evaluate a global population trend for this species, in contrast to literature that considers the population to be stable (BirdLife International, 2004, 2006b). There is some evidence of colony extinctions (Fig. 1, Appendix). These may be old, such as in Corsica (Lavezzi Island after the 18th century, France; Vigne et al., 1991; Zotier \& Vidal, 2004) and Crete (Greece, Alcover et al., 1992), or recent, such as in Corsica (Forana Island 1908-1982, and Gargalo Island 1947-1980, France;

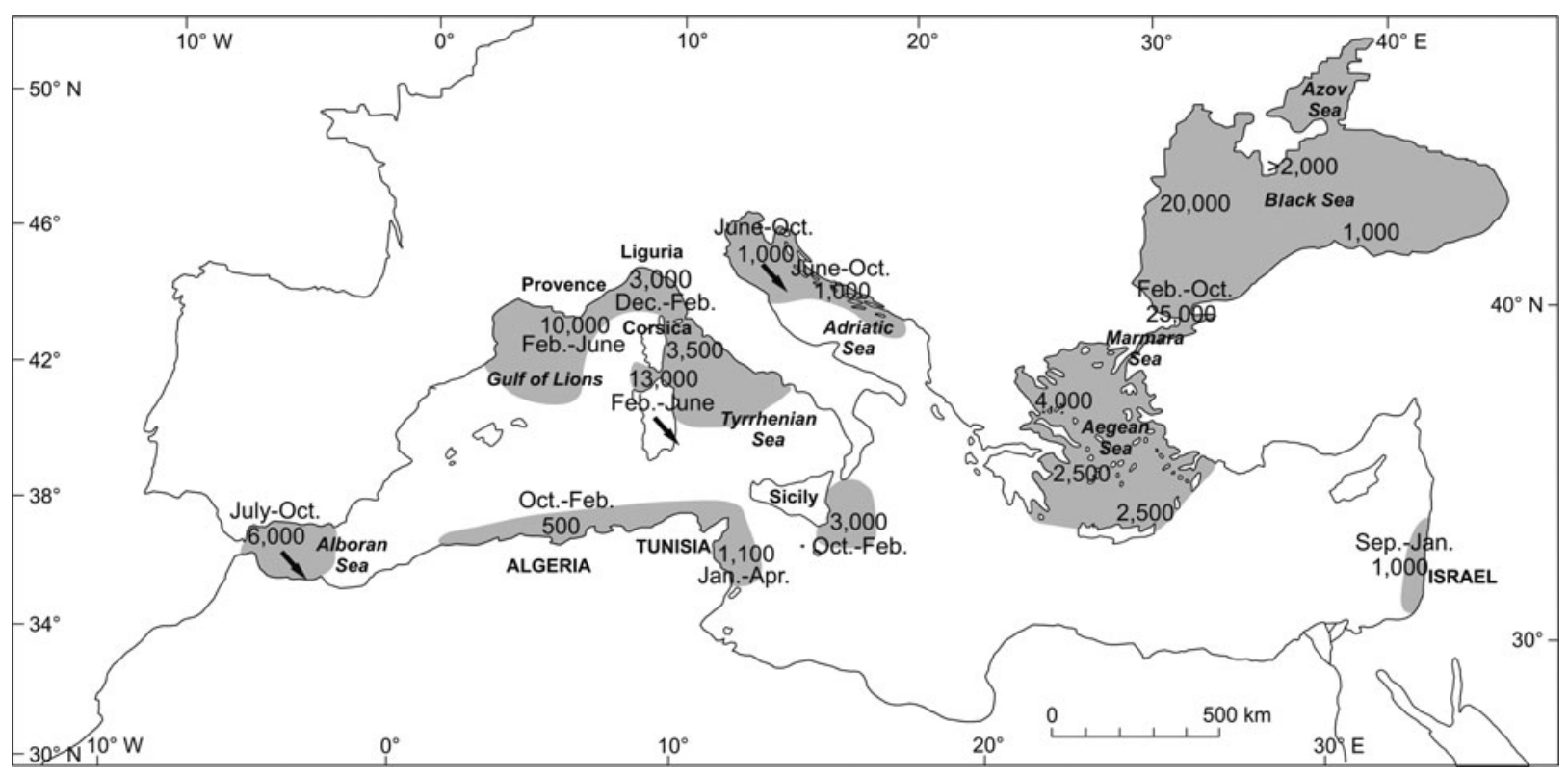

FIG. 2 Areas of yelkouan shearwater concentration at sea (passage, moulting and/or feeding), with maximum numbers, period of maximum occurrence (not indicated when occurrence is high throughout the year) and areas with decreasing numbers (indicated by an arrow). 
Guyot et al., 1985; Zotier \& Vidal, 2004), on French Mediterranean islands (Grand Congloué Islet 1954-1981; Zotier \& Vidal, 2004), Malta (Filfla Island in the early 1980s; Borg \& Sultana, 2002) and on Italian islands (Palmaria Island; Brichetti et al., 1992; Pianosa and Giannutri Islands 1989-2001; Tellini Florenzano et al., 1997; Arcamone \& Sposimo, 2002; N. Baccetti, pers. comm.). A total of nine extinctions have been documented, probably representing 300-400 breeding pairs, during the last 60 years. The causes of extinction are not clear but the authors suggested harvesting and predation by ship rats Rattus rattus (Vigne et al., 1991; Arcamone \& Sposimo, 2002). Breeding populations are also declining in the main breeding sites, with the same causes: Tuscany (Sposimo \& Tellini, 1995), Sardinia (vast sectors of Tavolara and Molara islands have been deserted; N. Baccetti, G. Spano \& M. Putzu, pers. comm.) and Malta (J.J. Borg, pers. comm.). Combining data for population extinctions and declines, the main yelkouan shearwater populations for which approximate data are available (France, Italy and Malta), may have decreased by $12-15 \%$ (i.e. $1,500-2,500$ breeding pairs) during the last 60 years.

The number of individuals in marine areas where the species concentrates could also be declining (Fig. 2). In the Alboran Sea large concentrations of up to 6,000 birds regularly occurred in the 1960 s and the early 1970 s but numbers have decreased to flocks of a maximum of 1,000 in certain years only (Thévenot et al., 2003). Hundreds to thousands of yelkouan shearwaters stayed around Corsica (Bonifacio Strait, north of Cape Corse, western gulfs) from December to June during the 1970 s and mid 1980 s but numbers now fluctuate from several tens to a few hundreds (Thibault \& Bonaccorsi, 1999). In the Gulf of Trieste (northern Adriatic Sea) hundreds of yelkouan shearwaters were regularly present from June to October (up to 1,000 in September) but this number has recently decreased (Brichetti \& Fracasso, 2003). These data suggest that the number of yelkouan shearwater at sea may have decreased by $>50 \%$ over the last 40 years.

\section{Major threats}

Table 1 summarizes the generally scarce information about threats to yelkouan shearwaters both at sea and in breeding colonies. The most well-documented and serious threat is the impact of introduced predators, especially feral cats Felis catus. For example, on the Hyères islands (French Mediterranean coast) feral cats have been identified as the primary predator of yelkouan shearwaters: shearwater remains were found in up to $6 \%$ of cat scats, representing hundreds of adults killed each year, especially during the pre-breeding period (Tranchant et al., 2003; Bonnaud et al., 2007). The ship rat has long been introduced on most of the Mediterranean islands and is now present on all the islands with yelkouan shearwater colonies (Martin et al., 2000). Ship rats may dramatically reduce breeding success of shearwaters during rat population peaks (Vidal, 1985). Breeding success was zero because of ship rat predation on the Tavolara islands in 2006 and on Montecristo Island in some years (Italy, N. Baccetti, G. Spano \& M. Putzu, pers. comm.). Rats are also the main cause of breeding failure in the largest Maltese colony (J.J. Borg, pers. comm.).

Rare cases of predation by native predators have been reported (Vidal \& Bayle, 1997; Zotier, 1997; Pieper \& Ristow, 2002). Competition for breeding habitat with Cory's shearwater Calonectris diomedea seems limited (Bourgeois \& Vidal, 2007). Harvesting of yelkouan shearwaters was frequent until the 1980s on most sites (Krpan, 1970; Vigne et al., 1991) but is now limited and the species is legally protected. Increasing tourism and coastal urbanization in the Mediterranean disturbs colonies and damages fragile breeding habitats (James, 1984; Gallo-Orsi, 2003; K. Bourgeois \& E. Vidal, pers. obs.).

Little is known about mortality of yelkouan shearwaters at sea as a result of accidental bycatch in long-lines and fishing nets. In the 1970 s net bycatch of yelkouan shearwaters off the south-east French coast was estimated at 800 per year (Besson, 1973) and dead yelkouan shearwaters are regularly found with signs of netting (head and neck without feathers and with net remains; IMEP, unpubl. data). More recently, some yelkouan shearwater deaths from long-lines have also been reported in the Gulf of Lions (J. González-Solís, C.C. Matet \& S.R. Moreno, pers. comm.), Straits of Bonifacio, Italian waters and around Malta (Cooper et al., 2003). At-sea mortality could be one of the major causes of the dramatic decline of the Balearic shearwater (Oro et al., 2004) and is probably similarly affecting the yelkouan shearwater.

The main fish species caught by fisheries in the Mediterranean (Lleonart \& Maynou, 2003) are the main prey items of yelkouan shearwaters (Zotier, 1997; Conéjéro \& Beaubrun, 2000; Stipčević \& Lukač, 2001). Such resource competition can induce changes in food availability and may affect seabird breeding success, adult survivorship, colony attendance and prey switching (Furness, 2003; Karpouzi, 2005). High levels of some contaminants have been detected in Mediterranean seabird tissues, thus weakening adults and decreasing breeding success (Lambertini \& Leonzio, 1986; Renzoni \& Massa, 1993). Intense maritime traffic in the Mediterranean increases the risk of oil spills.

\section{Reappraisal of conservation status}

IUCN Red List criteria for determining the degree of threat to species are based on population size, range and trends (IUCN, 2001). Considering the probable decrease in the yelkouan shearwater population by $12-50 \%$ (breeding 
TABLE 1 Overview of threats to the yelkouan shearwater in breeding colonies and at sea. Data type indicates if causes of mortality were quantified, observed, or only suspected.

\begin{tabular}{|c|c|c|c|c|c|}
\hline Causes of mortality & & Data type & Study area & Level of threat & Research priorities \\
\hline \multicolumn{6}{|l|}{ In breeding colonies } \\
\hline \multirow[t]{2}{*}{ Introduced predators } & Feral cat Felis catus & Quantified & Hyères islands, France & High & $\begin{array}{l}\text { Increase study sites to quantify } \\
\text { impacts on the overall population }\end{array}$ \\
\hline & Ship rat Rattus rattus & Quantified & Hyères islands, France & Potentially high & $\begin{array}{l}\text { Increase study sites to quantify } \\
\text { impacts on the overall population }\end{array}$ \\
\hline \multirow{3}{*}{ Indigenous predators } & Eagle owl Bubo bubo & Quantified & Marseille islands, France & Low & \\
\hline & Peregrine falcon Falco peregrinus & Quantified & Archipelago off Crete & Low & \\
\hline & $\begin{array}{l}\text { Yellow-legged gull } \\
\text { Larus michahellis }\end{array}$ & Quantified & Hyères islands, France & Medium & $\begin{array}{l}\text { Interaction studies in sympatric } \\
\text { breeding sites }\end{array}$ \\
\hline $\begin{array}{l}\text { Competition for } \\
\text { breeding sites }\end{array}$ & $\begin{array}{l}\text { Cory's shearwater } \\
\text { Calonectris diomedea }\end{array}$ & Quantified & Hyères islands, France & Low, locally high & $\begin{array}{l}\text { Interaction studies in sympatric } \\
\text { breeding sites }\end{array}$ \\
\hline \multirow[t]{2}{*}{ Disturbance } & Lights & Observed & Hyères islands, France & Low & \\
\hline & Tourism & Observed & Hyères islands, France & Potentially high & $\begin{array}{l}\text { Identification \& diagnosis } \\
\text { of breeding sites }\end{array}$ \\
\hline Habitat degradation & Urbanization, tourism & Observed & Hyères islands, France & Medium & $\begin{array}{l}\text { Identification \& diagnosis of } \\
\text { breeding sites }\end{array}$ \\
\hline Harvesting & Adults, eggs, chicks & Observed & $\begin{array}{l}\text { Balearic islands, Corsica, } \\
\text { Croatia, Egadi islands }\end{array}$ & Low, locally high & \\
\hline \multicolumn{6}{|l|}{ At sea } \\
\hline \multirow[t]{3}{*}{ Fisheries } & $\begin{array}{l}\text { Accidental captures in } \\
\text { drift- \& gill-nets }\end{array}$ & Observed & $\begin{array}{l}\text { Off south-east French } \\
\text { coast }\end{array}$ & High & $\begin{array}{l}\text { Impact quantification for the } \\
\text { overall population }\end{array}$ \\
\hline & $\begin{array}{l}\text { Accidental captures on } \\
\text { long-lines }\end{array}$ & Observed & $\begin{array}{l}\text { Gulf of Lions, Straits of } \\
\text { Bonifacio, Italian waters, } \\
\text { around Malta }\end{array}$ & High & $\begin{array}{l}\text { Impact quantification for } \\
\text { the overall population }\end{array}$ \\
\hline & $\begin{array}{l}\text { Decrease in food } \\
\text { availability }\end{array}$ & Suspected & & Potentially high & Survey of prey availability \\
\hline \multirow[t]{2}{*}{ Pollution } & Biocontamination & Suspected & & Potentially high & $\begin{array}{l}\text { Quantification of biocontaminants } \\
\text { with sanitary \& breeding monitoring }\end{array}$ \\
\hline & Oil spills & Suspected & & Potentially high & Search for affected birds \\
\hline
\end{tabular}


population and at sea) and the fact this reduction and its causes have not ceased and are not fully identified, the species should be considered at least Near Threatened. The Near Threatened classification acknowledges the possibility that future research will qualify the species for inclusion in a threatened category (IUCN, 2001). In the same way, the species' Secure European threat status (BirdLife International, 2004a) should be reviewed and possibly revised in the light of future research.

\section{Discussion}

This review emphasizes the lack of available data for the yelkouan shearwater. Purported yelkouan shearwater breeding sites require confirmation, particularly in Turkey and Greece. Breeding population censuses are needed at colonies, particularly on purported major breeding sites such as in Sardinia, Sicily and Greece. In addition, the biology and ecology of this species are still poorly known and research is therefore required for the design of an appropriate conservation strategy. In particular, demographic monitoring is a prerequisite for assignment of species conservation status. The impact of introduced predators on the yelkouan shearwater has been demonstrated but studied only in small populations. Control and/or eradication of introduced predators (particularly cats and rats) should be a conservation priority. The removal of rabbits and house mice from the Atlantic island of Selvagem Grande, for example, was beneficial to the breeding of Cory's shearwaters Calonectris diomedea borealis (Zino et al., 2008).

Accidental bycatch in fishing gear has been identified as a major threat for medium and large Procellariforms (Brooke, 2004) but few data are available for the yelkouan shearwater. Consequently, quantification of this impact is required, as is the identification of Marine Important Bird Areas (BirdLife International, 2004b) for this species. Breeding site protection, especially against introduced predators, and at-sea threat prevention, were initiated in France in 2003 (Marseille and Hyères islands) and are beginning in Malta with the help of funding from three EU LIFE Nature programmes. However, the yelkouan shearwater distribution comprises at least 10 countries and international collaboration is necessary for the preservation of this Mediterranean endemic species. We thus encourage such collaborations to assess the global situation for the species and coordinate conservation actions. Finally, we call for more data on the yelkouan shearwater, particularly regarding demography and ecology, and for an evaluation of terrestrial and marine threats. Such data are also lacking for many seabirds, particularly Procellarids (IUCN, 2007), and an effort to complete our knowledge regarding these issues would improve prioritization of conservation actions for seabirds.

\section{Acknowledgements}

Funds and support were provided by the European Union, the Direction Régionale de l'Environnement ProvenceAlpes-Côte d'Azur, and the Conseil Regional ProvenceAlpes-Côte d'Azur through the granting of a Life Nature project to Ligue pour la Protection des Oiseaux ProvenceAlpes-Côte d'Azur (ref. LIFE03NAT/F000105). We are very grateful to $\mathrm{G}$. Aplington, H. Azafzaf, N. Baccetti, S. Baris, P. Brichetti, J.J. Borg, G. Bundi, F. Corbi, T. Gaultier, M. Genovart, J. González-Solís, J. Legrand, G. Lukač, A. Maoli, C.C. Matet, S.R. Moreno, D. Oro, M. Putzu, V. Satta, G. Spano, J.C. Thibault and R. Zotier for responding to our correspondence and sharing their information. We also thank the library of the Tour du Valat. Thanks to I. Burfield and an anonymous referee for their valuable comments on the manuscript, G. Lukač for translating some parts of Croatian papers, and to C.M. Suehs for help with English.

\section{References}

Alcover, J.A., Florit, F., Mourer-Chauviré, C. \& Weesie, P.D.M. (1992) The avifaunas of the isolated Mediterranean islands during the Middle and Late Pleistocene. Contributions in Science Series, National History Museum of Los Angeles, 36, $273-283$.

Arcamone, E. \& Sposimo, P. (2002) Indagine sull'avifauna nidificante e aggiornamenti alla check-list dell'Isola di Pianosa (Archipelago Toscano). Rivista Italiana di Ornitologia, 71, 89-102.

Arcos, J.M. \& Oro, D. (2004) Pardela Balear, Puffinus mauretanicus. In Libro Rojo de las Aves de España (eds A. Madroño, C. González \& J.C. Atienza), pp. 46-50. Dirección General para la Biodiversidad-Sociedad Española de Ornitologia/BirdLife, Madrid, Spain.

B accetti, N. (1994) Uccelli marini nidificanti sull'Isola di Montecristo (Arcipelago Toscano). Quaderni del Museo di Storia Naturale di Livorno, Monographie, 13, 23-29.

Besson, J. (1973) Remarques sur la mort accidentelle de puffins yelkouans. Alauda, 41, 165-167.

Bibby, C.J., Burgess, N.D. \& Hill, D.A. (1992) Bird Census Techniques. Academic Press, San Diego, USA.

Birdife International (2004a) Birds in Europe: Population Estimates, Trends and Conservation Status. BirdLife Conservation Series no. 12, BirdLife International, Cambridge, UK.

BirdLife InTERNATIONAL (2004b) Tracking Ocean Wanderers: The Global Distribution of Albatrosses and Petrels. Results from the Global Procellariiform Tracking Workshop, 1-5 September, 2003, Gordon's Bay, South Africa. BirdLife International, Cambridge, UK.

BirdLife International (2005) World Bird Database: The Site for Bird Conservation, v. 2.o. BirdLife International, Cambridge, UK. Http://www.birdlife.org/datazone/sites/index. html ?action $=$ SitHTMFindResults.asp $\&$ INam $=\&$ Reg $=7 \&$ Cty $=84$ [accessed 30 May 2006].

BirdLife International (2006a) Species Factsheet: Puffinus mauretanicus. BirdLife International, Cambridge, UK. Http://www. birdlife.org/datazone/species/index.html?action=SpcHTMDetails. asp\&sid $=30026 \& \mathrm{~m}=0$ [accessed 15 November 2006]. 
BirdLife International (2006b) Species Factsheet: Puffinus yelkouan. BirdLife International, Cambridge, UK. Http://www.birdlife.org/ datazone/species/index.html?action=SpcHTMDetails.asp\&sid= $3937 \& \mathrm{~m}=0$ [accessed 15 November 2006].

Bonnaud, E., Bourgeois, K., Vidal, E., Kayser, Y., Tranchant, Y. \& Legrand, J. (2007) Feeding ecology of a feral cat population on a small Mediterranean island. Journal of Mammalogy, 88, 1074-1081.

Borg, J.J. \& Sultana, J. (2002) Status and distribution of the breeding Procellariiformes in Malta. Il-Merill, 30, 10-15.

Bourgeois, K. \& VidAL, E. (2007) Yelkouan shearwater nest-cavity selection and breeding success. Comptes Rendus Biologies, 330, 205-214.

Bourne, W.R.P., Mackrill, E.J., Paterson, A.M. \& Yésou, P. (1988) The yelkouan shearwater Puffinus (puffinus?) yelkouan. British Birds, 81, 306-319.

B RichetTI, P. (1988) Distribuzione geografica degli uccelli nidificanti in Italia, Corsica e Isole Maltesi. V. Aggiornamenti e Rettifiche. Natura Bresciana, 24, 147-174.

Brichetti, P., De Franceschi, P \& Baccetti, N. (1992) Fauna d'Italia, Aves 1: Gaviidae-Phasianidae. Calderini, Bologna, Italia.

Brichetti, P. \& Fracasso, G. (2003) Ornithologia Italiana, Vol. 1: Gaviidae-Falconidae. Alberto Perdisa, Bologna, Italia.

B ro oke, M. (1990) The Manx Shearwater. Academic Press, London, UK.

Brooke, M. (2004) Albatrosses and Petrels across the World. Oxford University Press, New York, USA.

Bundy, G. (1976) The Birds of Libya. British Ornithologists' Union, London, UK.

Butchart, S.H.M., Statterfield, A.J., Bennun, L.A., Shutes, S.M., Акс̧Акау A, H.R., B Aillie, J.E.M. et al. (2004) Measuring global trends in the status of biodiversity: Red List Indices for birds. Public Library Of Science, Biology, 2, 2294-2304.

Conéjéro, S. \& BeAubrun, P. (2000) Cory's shearwater Calonectris diomedea and Levantine shearwater Puffinus yelkouan (Procellariidea) in the Gulf of Lions during July 1994. In Monitoring and Conservation of Birds, Mammals and Sea Turtles of the Mediterranean and Black Seas (eds P. Yésou \& J. Sultana), pp. 104-105. MEDMARAVIS, Gozo, Malta.

Cooper, J., Baccetti, N., Belda, E.J., Borg, J.J., Oro, D., Papaconstantinou, C. et al. (2003) Seabird mortality from long-line fishing in the Mediterranean Sea and Macaronesian waters: a review and a way forward. Scientia Marina, 67, 57-64.

Deleuil, R. (1954) Prospection ornithologique des îles de Zembretta et Zembra. In Contributions à l'exploration scientifique des îles Aegimures (Zembra et Zembretta) (ed. Société des Sciences Naturelles de Tunisie), pp. 19-31. Mémoires de la Société des Sciences Naturelles de Tunisie no. 2, Tunis, Tunisia.

Demartis, A.M. (1986) Seabirds of the southern Sardinian islets. In Mediterranean Marine Avifauna: Population Studies and Conservation (eds MEDMARAVIS \& X. Monbailliu), pp. 19-30. NATO ASI Series, Vol. G 12, Munich, Germany.

Donlan, C.J. \& Wilcox, C. (2008) Integrating invasive mammal eradications and biodiversity offsets for fisheries bycatch: conservation opportunities and challenges for seabirds and sea turtles. Biological Invasions, in press.

Flint, P.R. \& Stewart, P.F. (1992) The Birds of Cyprus. British Ornithologists' Union, Tring, UK.

FurNESS, R.W. (2003) Impacts of fisheries on seabird communities. Scientia Marina, 67 (Suppl. 2), 33-45.

GALLO-OrSi, U. (2003) Species action plans for the conservation of seabirds in the Mediterranean Sea: Audouin's gull, Balearic shearwater and Mediterranean shag. Scientia Marina, $67,47-55$.
GASKelL, J. (2005) Recent changes in the status and distribution of birds in Libya. Sandgrouse, 27, 126-138.

Goodman, S.M. \& Meininger, P.L. (1989) The Birds of Egypt. Oxford University Press, Oxford, USA.

Guyot, I., Launay, G. \& Vidal, P. (1985) Oiseaux de mer nicheurs du Midi de la France et de Corse: évolution et importance des effectifs. In Oiseaux Marins Nicheurs du Midi et de la Corse (eds J.C. Thibault, I. Guyot \& G. Cheylan), pp 31-47. Centre Régional Ornithologique de Provence, Aix-en-Provence, France.

Handrinos, G. \& Akriotis, T. (1997) The Birds of Greece. Christopher Helm Publishers, London, UK.

Heidrich, P., Amengal, J. \& Wink, M. (1998) Phylogenetic relationships in Mediterranean and North Atlantic shearwaters (Aves: Procellariidae) based on nucleotide sequences of mtDNA. Biochemical Systematics and Ecology, 26, 145-170.

Iapichino, C. \& Massa, B. (1989) The Birds of Sicily. British Ornithologists' Union, Tring, UK.

Isenmann, P., Gaultier, T., El Hili, A., Azafzaf, H., Dlensi, H. \& Smart, M. (2005) Birds of Tunisia. Société d'Etudes Ornithologiques de France, Paris, France.

Isenmann, P. \& Moali, A. (2000) Birds of Algeria. Société d'Etudes Ornithologiques de France, Paris, France.

IUCN (2001) 2001 Categories and Criteria (version 3.1). IUCN, Gland, Switzerland [http://www.redlist.org/info/categories_criteria2001. html, accessed 15 November 2006].

IUCN (2007) 2007 IUCN Red List of Threatened Species. IUCN, Gland, Switzerland. Http://www.iucnredlist.org [accessed 16 January 2007].

James, P.C. (1984) The status and conservation of seabirds in the Mediterranean Sea. International Council for the Preservation of Birds Technical Publication, 2, 371-375.

Karpouzi, V.S. (2005) Modelling and mapping trophic overlap between fisheries and the world's seabirds. MSc thesis, University of British Columbia, Vancouver, Canada [http://www.fisheries.ubc.ca/grad/abstracts/karpouzithesis.pdf, accessed 17 June 2006].

Kirwan, G.M., Martins, R.P., Eken, G. \& Davidson, P. (1999) A checklist of the birds of Turkey. Sandgrouse, 21 (Suppl. 1), $1-32$.

Krpan, M. (1970) Prilog poznavanjuornitofaune otoka Lastova. Larus, 21-22, 65-83.

Krpan, M. (1976-1977) Prilog ornitofauni otoka Korčule. Larus, 29-30, 93-121.

Kumerloeve, H. (1966) Liste systématique révisée des espèces d'oiseaux de Turquie. Alauda, 34, 165-186.

Lambertini, M. \& Leonzio, C. (1986) Pollutant levels and their effects on Mediterranean seabirds. In Mediterranean Marine Avifauna: Population Studies and Conservation (eds MEDMARAVIS \& X. Monbailliu), pp. 359-378. NATO ASI Series, Vol. G 12, Munich, Germany.

Ledant, J.P., Jacob, J.P., Jacobs, P., Malher, F., Ochando, B. \& Roché, J. (1981) Mise à jour de l'avifaune algérienne. Le Gerfaut, 7, 295-398.

Lleonart, J. \& Maynou, F. (2003) Fish stock assessments in the Mediterranean: state of the art. Scientia Marina, 67 (Suppl. 1), 37-49.

Lovrić, A.Ž. (1971) Ornitogene biocenoze u Kvarneru. Larus, 23, $39-72$.

Lovrić, A.Ž. \& Obradovic, J. (1988) Nesting areas and synecology of seabirds in Adriatic islets. Rapport de la Comission Internationale pour l'Exploration Scientifique de la Mer Méditerranée, Monaco, 31, 130.

Markovec, T. (1995) Pojavljanje sredozemskega viharnika Puffinus yelkouan na slovenski obali. Falco, 9, 17-20. 
Martin, J.L., Thibault, J.C. \& Bretagnolle, V. (2000) Black rats, island characteristics, and colonial nesting birds in the Mediterranean: consequences of an ancient introduction. Conservation Biology, 14, 1452-1466.

Meininger, P.L., Wolf, P.A., Hadoud, D.A. \& Essghaier, M.F.A. (1996) Notes on the coastal birds of Libya, July 1993. Sandgrouse, 18, 53-60.

NANKIn Ov, D. (1993) Status and conservation of breeding seabirds in Bulgaria. In Status and Conservation of Seabirds: Ecography and Mediterranean Action Plan (eds J.S. Aguilar, X. Monbailliu \& A.M. Paterson), pp. 173-180. Sociedad Española de Ornitologia, Madrid, Spain

Nankinov, D.N. (2001) Migration, seasonal and spatial distribution of Manx shearwater, Puffinus puffinus in the Black Sea basin. Proceedings of Institute of Oceanology, Varna, 3, 170-179.

Oro, D., Aguilar, J.S., Igual, J.M. \& Louzao, M. (2004) Modelling demography and extinction risk in the endangered Balearic shearwater. Biological Conservation, 116, 93-102.

Pieper, H. \& Ristow, D. (2002) Prey of a peregrine falcon Falco peregrinus pair off Crete. Il-Merill, 30, 29-31.

Rabouam, C., Ribeyre, J.P., Seguin, J.F., Thibault, J.C. \& Zotier, R. (1995) Les oiseaux marins reproducteurs des îles mineures de La Maddalena (Bouches de Bonifacio). Travaux Scientifiques du Parc Naturel Régional et des Réserves Naturelles de Corse, 56, 71-81.

Renzoni, A. \& Massa, A. (1993) Contaminants in Mediterranean seabirds. In Status and Conservation of Seabirds: Ecography and Mediterranean Action Plan (eds J.S. Aguilar, X. Monbailliu \& A.M. Paterson), pp. 207-212. Sociedad Española de Ornitologia, Madrid, Spain.

Ristow, D. (1998) The prospectors in a colony of Cory's shearwater Calonectris diomedea. In Ecologie des Oiseaux Marins et Gestion Intégrée en Méditerranée (eds Association les Amis des Oiseaux \& MEDMARAVIS), pp. 70-91. Editions Arcs, Tunis, Tunisia.

Sangster, G., Collinson, J.M., Helbig, A.J., Knox, A.G. \& PARKIN, D.T. (2002) The specific status of Balearic and yelkouan shearwaters. British Birds, 95, 636-639.

Schenk, H. (1995) Status faunistico e di conservazione dei vertebrati (Amphibia, Reptilia, Aves, Mammalia) riproducentesi in Sardegna, 1900-93: contributo preliminare. In Studio, Gestione e Conservazione della Fauna Selvatica in Sardegna, Atti del $1^{\circ}$ Convegno regionale sulla fauna selvatica in Sardegna (eds S. Cossu, P. Onida \& A. Torre), pp. 41-95. Edizioni del SoleAmministrazione provinciale di Oristano, Italia.

SChenk, H. \& Torre, A. (1986) Breeding distribution, numbers and conservation of seabirds in Sardinia, 1978-85. In Mediterranean Marine Avifauna: Population Studies and Conservation (eds MEDMARAVIS \& X. Monbailliu), pp. 449-463. NATO ASI Series, Vol. G 12, Munich, Germany.

Shirihai, H., Dovrat, E. \& Christie, D.A. (1996) The Birds of Israel. Academic Press, London, UK.

Sposimo, P. \& Tellini, G. (1995) Lista rossa degli uccelli nidificanti in Toscana. Rivista Italiana di Ornitologia, 64, 131-140.

Stipčević, M. \& Lukač, G. (2001). Status of tubenose seabirds Procellariiformes breeding in the eastern Adriatic. Acrocephalus, 22, 9-21.

Tellini Florenzano, G., Baccetti, N., Arcamone, E., Meschini, E. \& Sposimo, P. (1997) Atlante degli uccelli nidificanti e svernanti in Toscana (1982-1992). Quaderni del Museo di Storia Naturale di Livorno, Monographie, 1, 1-414.
Tha Rwat, M.E. (1997) Birds Known to Occur in Egypt. National Biodiversity Unit no. 8, Egyptian Environmental Affairs Agency, Cairo, Egypt.

Thévenot, M., Vernon, R. \& Bergier, P. (2003) The Birds of Morocco. British Ornithologists' Union, Tring, UK.

Thibault, J.C. \& Bonaccorsi, G. (1999) The Birds of Corsica. British Ornithologists' Union, Tring, UK.

Torre, A. (2003) L'avifauna nidificant al territori communal de L'Alguer. Les espècies de la costera marina alta (Penya segat): birriquella. L'Alguer, periòdic de cultura i informació86 no. 86. [http://www.publivideo.it/alguer/86.htm, accessed 30 May 2006].

Tranchant, Y., Vidal, E. \& Kayser, Y. (2003) Premières données sur le régime alimentaire du chat haret Felis catus en situation micro-insulaire Méditerranéenne. Revue d'Ecologie (Terre \& Vie), $58,411-418$.

W arham, J. (1990) The Petrels: Their Ecology and Breeding Systems. Academic Press, London, UK.

Vid AL, P. (1985) Premières observations sur la biologie de la reproduction du puffin des Anglais Puffinus puffinus yelkouan sur les îles d'Hyères (France). In Oiseaux Marins Nicheurs du Midi et de la Corse (eds J.C. Thibault, I. Guyot \& G. Cheylan), pp. 5862. Centre Régional Ornithologique de Provence, Aix-en-Provence, France.

VidAL, P. \& B A YLE, P. (1997) Le grand-duc d'Europe Bubo bubo: une nouvelle espèce d'oiseau nicheuse sur les îles de Marseille (Bouches-du-Rhône). Faune de Provence (CEEP), 18, 55-57.

Vigne, J.D., Lefìvre, C., Thibault, J.C. \& Guyot, I. (1991) Contribution archéozoologique à l'histoire récente des oiseaux marins de l'île Lavezzi (Corse XIV-XVème siècles). Alauda, $59,11-21$.

Zino, F., Hounsome, M.V., Buckle, A.P. \& Biscoito, M. (2008) Was the removal of rabbits and house mice from Selvagem Grande beneficial to the breeding of Cory's shearwaters Calonectris diomedea borealis? Oryx, 42, 151-154.

Zotier, R. (1997) Biogéographie des oiseaux marins en Méditerranée et écologie d'un Procellariiforme endémique: le puffin de Méditerranée Puffinus yelkouan. EPHE thesis, Université Montpellier II, Montpellier, France.

Zotier, R., Thibault, J.C. \& Guyot, I. (1992) Known population and distribution of cormorants, shearwaters and storm petrels in the Mediterranean. Avocetta, 16, 118-126.

Zotier, R. \& Vidal, P. (2004) Puffin yelkouan. In Oiseaux Marins Nicheurs de France Métropolitaine (1960-200o) (eds B. Cadiou, J.M. Pons \& P. Yésou), pp. 58-61. Editions Biotope, Mèze, France.

\section{Appendix}

The appendix for this article is available online at http:// journals.cambridge.org

\section{Biographical sketches}

KAREN Bourgeois has been studying the ecology, biology and conservation of the yelkouan shearwater for 6 years, and previously participated in a LIFE programme on shearwater conservation on the Hyères Islands for 3 years. Her main research interests are the ecology and conservation of seabirds. ERIC VID AL researches the ecology and dynamics of seabirds, particularly in the Mediterranean, and the functioning of island ecosystems, especially the role of biotic interactions and the impact of invasive species. 